\title{
Ice-core evidence of westerly and monsoon moisture contributions in the central Tibetan Plateau
}

\author{
Daniel R. JOSWIAK, Tandong YAO, Guangjian WU, Lide TIAN, Baiqing XU \\ Key Laboratory of Tibetan Environment Changes and Land Surface Processes, Institute of Tibetan Plateau Research, \\ Chinese Academy of Sciences, Beijing, China \\ E-mail: daniel@itpcas.ac.cn
}

\begin{abstract}
Stable isotopes are a primary tool for inferring past temperature changes and atmospheric moisture variability from ice cores. A $33 \mathrm{~m}$ ice core representing the period 1850-2004 was retrieved from the Tanggula Mountains, central Tibetan Plateau (5743 ma.s.l.), in August 2005. Annual average stable isotope $\left(\delta^{18} \mathrm{O}, \delta \mathrm{D}\right)$ values generally increase during the period, while the second-order parameter of deuterium excess (d-excess) generally decreases. High annual average d-excess values $(\mathbf{1 8 . 2 \%})$ throughout the ice core suggest a significant contribution of continental recycled moisture. $d$-excess values shift from relatively higher values during 1850-1940 to lower values since the 1940s. Annual isotope values and reconstructed accumulation are compared with climate indices, local station temperature records and northern India monsoon precipitation. Significant correlation is observed between $\delta^{18} \mathrm{O}$ and the Southern Oscillation, NINO3.4 and Dipole Mode indices. Annual average d-excess values revealed a significant negative correlation with the Dipole Mode index. Results suggest a relatively greater contribution of westerly-dominated continental moisture prior to the 1940s and an increase in the contribution of moisture evaporated under more humid conditions since the 1940s.
\end{abstract}

\section{INTRODUCTION}

High-elevation ice cores provide an ideal means to infer past atmospheric composition and moisture source changes from the geochemical signals preserved in snow and ice. Stable isotopes in ice cores from the central Tibetan Plateau (TP) have previously been used for temperature reconstructions (Thompson and others, 2006; Kang and others, 2007), for inferring moisture source variability (Tian and others, 2001a, 2005) and to document variability of the south Asian monsoon (Tian and others, 2001b,c). However, the vast TP, which covers over $10^{\circ}$ latitude and nearly $30^{\circ}$ longitude (Fig. 1), contains regions influenced by different circulation systems and moisture sources, resulting in a region that impacts isotopes in precipitation in different and opposing manners (Araguás-Araguás and others, 1998; Tian and others, 2001a).

In the northern TP (Fig. 1), moisture arrives with the westerlies and is dominated by strong continental recycling and convective precipitation. In these continental regions, stable isotopes in snow and ice preserve a temperature signal; more depleted values occur during the winter, with lower temperatures, and less depleted values occur during the summer with higher temperatures. For example, ice cores from Guliya and Dunde ice caps (Yao and others, 1996), Puruogangri icefield (Thompson and others, 2006; Yao and others, 2006) and Malan ice cap (Wang and others, 2003a) correlate well with instrumental temperature data. This is recognized as the typical isotopic dependence on temperature observed at continental locations (Rozanski and others, 1993).

In the southern TP (Fig. 1), the main precipitation occurs during the south Asian monsoon season from June to September (Tian and others, 2001b). Moisture during the monsoon season may be transported over northern India from dual sources of the Arabian Sea and the Bay of Bengal (Sengupta and Sarkar, 2006). In regions of the southeastern $\mathrm{TP}$, especially in the Himalaya, the opposite relationship between stable isotopes and temperature exists: heavy amounts of depleted monsoon precipitation arrive from humid oceanic origins during the warm season, resulting in a negative isotope-temperature correlation (Araguás-Araguás and others, 1998; Qin and others, 2000; Tian and others, 2001c; Kang and others, 2002; Vuille and others, 2005).

The central TP is situated between the previously described opposing oxygen-18 relationships (temperature dependence and monsoon impact), which complicates temperature and atmospheric reconstructions from isotope proxy records. Westerly atmospheric circulation dominates during the winter, with westerly surface winds split into northern and southern branches. The westerly jet is pushed northward during the summer, and the maximum extent of the south Asian monsoon is associated with the characteristic trough east of the Indian subcontinent (Vuille and others, 2005). The converging circulation systems provide atmospheric moisture to the central TP from vastly different source regions and distinct transport histories. Although long-term isotope data from precipitation in the central TP are sparse, prior results (Ohata and others, 1994; Tian and others, 2003; Zhang and others, 2007) have reported monsoon influences penetrating into the interior of the TP, manifested as an annual depletion of $\delta^{18} \mathrm{O}$ during the main monsoon precipitation period from June through September. The central TP receives over $85 \%$ of its annual precipitation during this time (Fig. 2). Monsoon-impacted regions typically have more depleted isotope values during the warm season, although these regions may still track temperature trends on longer timescales (Yu and others, 2008). Isotope relationships were further studied by Bradley and others (2003), demonstrating a significant positive correlation between Pacific sea surface temperatures (SSTs) and oxygen-18 isotope values in the Dasuopu ice core from the central Himalaya (Fig. 1). A more thorough understanding of isotope-temperature-monsoon relationships in the central TP is necessary in order to determine the 


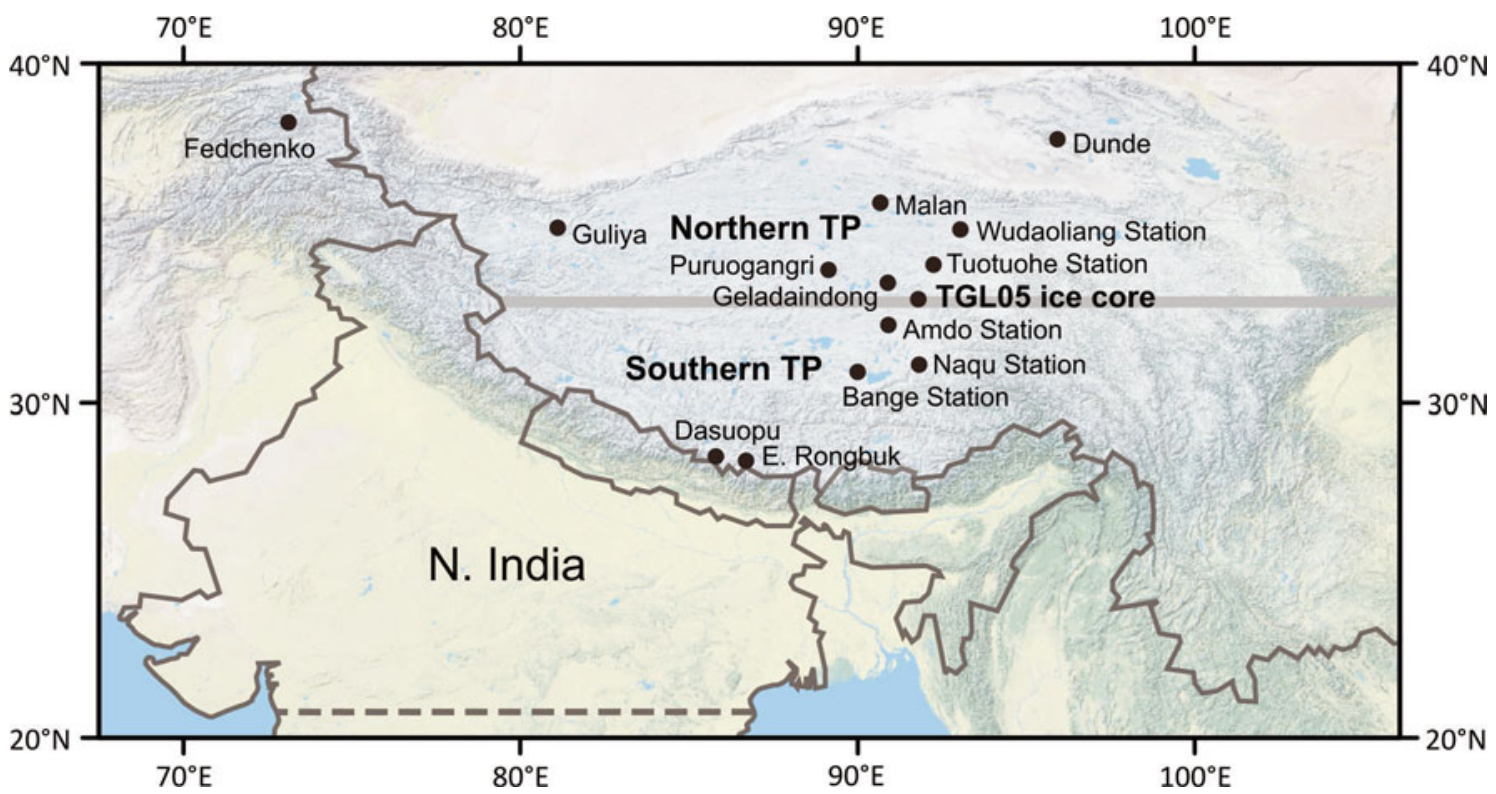

Fig. 1. Map of the study region showing ice-core locations, meteorological station locations and general climatological division between the northern and southern Tibetan Plateau at $33^{\circ} \mathrm{N}$ (in gray). Dashed line indicates area of northern India precipitation data used for analysis. Boundary lines are for reference only and may not denote actual political borders.

possibility of using a particular ice core for temperature or monsoon reconstructions in this region.

Increasing positive correlation between temperature and $\delta^{18} \mathrm{O}$ was previously established moving from the southern to the northern TP, indicating a gradual northward weakening of monsoon activity (Yu and others, 2008). The main region on the TP where tropical monsoon circulation interacts with westerly-dominated air masses coincides with the Tanggula Mountains at $\sim 33^{\circ} \mathrm{N}$ (Tian and others, 2001b; Thompson and others, 2006). The Tanggula Mountains in the central TP represent the main orographic barrier to the northern extent of the south Asian monsoon (Tian and others, 2001c). The ice core presented here was retrieved from the western Tanggula Mountains, a generally east-west trending mountain range with an average elevation of $>5000 \mathrm{~m}$ a.s.I. The Tanggula Mountains are situated in the central TP, directly within the boundary region of westerlyand monsoon-dominated moisture sources (Fig. 1). Previous results from the central TP revealed a significant correlation between oxygen-18 values and northern India precipitation for 1935-2004 (Joswiak and others, 2010). These results present the $\delta^{18} \mathrm{O}$ and $\delta \mathrm{D}$ analysis for the entire core depth, extending the results to the mid-19th century.

When $\delta^{18} \mathrm{O}$ and $\delta \mathrm{D}$ results from meteoric precipitation are available, the relationship of the local meteoric waterline $(\mathrm{LMWL})$ may be examined in comparison with the global meteoric waterline (GMWL: $\delta \mathrm{D}=8 \cdot \delta^{18} \mathrm{O}+10$; Craig, 1961) as the linear correlation of $\delta^{18} \mathrm{O}$ and $\delta \mathrm{D}$. The additive parameter of deuterium excess (d-excess) defined by Dansgaard (1964) is inherited from the initial isotopic composition of the precipitation sources and remains relatively constant during Raleigh rainout (Gat, 1996). $\mathrm{d}$-excess $\left(\mathrm{d}\right.$-excess $=\delta \mathrm{D}-8 \cdot \delta^{18} \mathrm{O}$; Dansgaard, 1964) is a second-order parameter mainly dependent on climate conditions at the surface water where the vapor was formed (Fröhlich and others, 2002). In general, water vapor evaporated from humid sources is less affected by kinetic processes, resulting in 'slower' evaporation and relatively lower d-excess values, while water evaporated in warmer or drier conditions leads to 'faster' evaporation farther from equilibrium, resulting in high d-excess values (Merlivat and Jouzel, 1979; Jouzel and Merlivat, 1984; Schwikowski and others, 2005; Aizen and others, 2009). LMWLs are often established at a particular location, despite the questionable meaning in regions impacted by different synoptic patterns or source characteristics of precipitation events (Gat, 1996).

Changes in $\mathrm{d}$-excess in precipitation were first used to estimate moisture recycling by Salati and others (1979) and Gat and others (1994). Mid-latitude ice-core proxy records have since been used to investigate relationships among $\mathrm{d}$-excess and moisture source, transport history and isotopic kinetic effects (Kreutz and others, 2003; Aizen and others, 2005, 2009; Schwikowski and others, 2005). Observations have also verified the relationship between d-excess in vapor and ocean surface conditions (Uemura and others, 2008). In the central TP, a large contribution of continental recycled moisture has been demonstrated using stable isotopes in

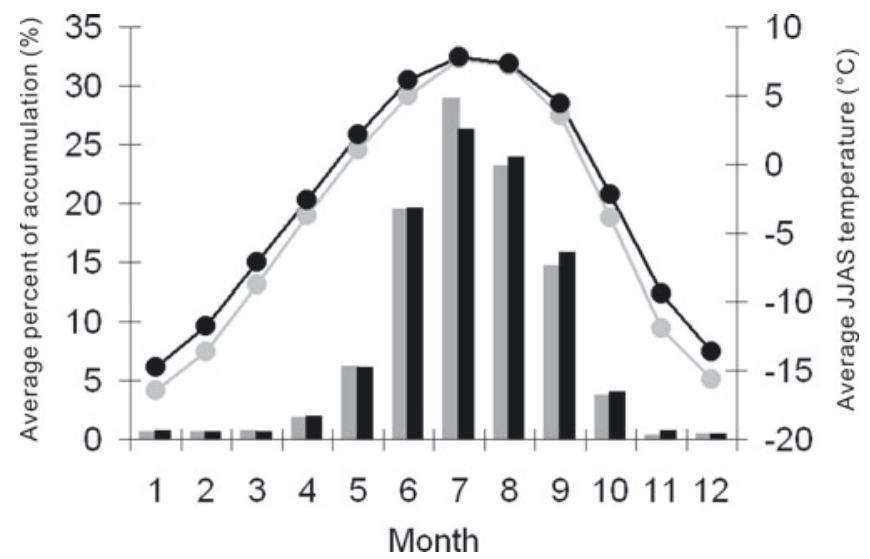

Fig. 2. Average temperature (lines) and precipitation distribution (bars) recorded at Amdo (black) and Tuotuohe (gray) stations. Time period is 1966-2004 for Amdo and 1957-2004 for Tuotuohe. 
Table 1. Ground-based meteorological station summary data. $P_{\mathrm{T}}$ is average total precipitation, $T_{\mathrm{A}}$ is average annual temperature and $T_{\mathrm{M}}$ is average monsoon (June-September) temperature

\begin{tabular}{|c|c|c|c|c|c|c|c|}
\hline Station & Period & Latitude & Longitude & $\begin{array}{c}\text { Elevation } \\
\text { ma.s.I. }\end{array}$ & $\begin{array}{c}P_{\mathrm{T}} \\
\mathrm{mm}\end{array}$ & $\begin{array}{l}T_{\mathrm{A}} \\
{ }^{\circ} \mathrm{C}\end{array}$ & $\begin{array}{l}{ }^{T_{M}} \\
{ }^{\circ} \mathrm{C}\end{array}$ \\
\hline Wudaoliang & 1957-2004 & $35^{\circ} 13^{\prime} \mathrm{N}$ & $93^{\circ} 05^{\prime} \mathrm{E}$ & 4612 & 276 & -5.4 & 3.8 \\
\hline Tuotuohe & 1957-2004 & $34^{\circ} 13^{\prime} \mathrm{N}$ & $92^{\circ} 26^{\prime} \mathrm{E}$ & 4533 & 278 & -4.1 & 5.8 \\
\hline Bange & 1957-2004 & $31^{\circ} 23^{\prime} \mathrm{N}$ & $90^{\circ} 01^{\prime} \mathrm{E}$ & 4507 & 308 & -1.1 & 7.6 \\
\hline Amdo & 1966-2004 & $32^{\circ} 21^{\prime} \mathrm{N}$ & $91^{\circ} 06^{\prime} \mathrm{E}$ & 4800 & 440 & -2.8 & 6.4 \\
\hline Naqu & 1955-2004 & $31^{\circ} 29^{\prime} \mathrm{N}$ & $92^{\circ} 04^{\prime} \mathrm{E}$ & 4700 & 429 & -1.4 & 7.6 \\
\hline
\end{tabular}

precipitation, near-surface moisture and evapotranspiration measurements (Kurita and Yamada, 2008). Precipitation sampling in the central Himalaya revealed comparatively higher $\mathrm{d}$-excess values associated with westerly transported moisture and lower values associated with southerly monsoon-season precipitation (Tian and others, 2005). The additional information preserved by d-excess makes it an important tool to aid in understanding and reconstructing moisture source contributions and transport history for accumulation preserved in ice cores.

\section{DATA AND METHODS}

The ice core presented here was obtained from the upper accumulation zone of Longxia Zailongba glacier $\left(33^{\circ} 7^{\prime} 4.26^{\prime \prime} \mathrm{N}, 92^{\circ} 5^{\prime} 26.16^{\prime \prime} \mathrm{E}\right.$; $5743 \mathrm{ma.s.l}$.) in August 2005. The $33 \mathrm{~m}$ core was retrieved with an electromechanical ice-core drill, transported to the State Key Laboratory of Cryospheric Sciences, Lanzhou, China, and processed for geochemical analysis. The ice-core sections for stableisotope and soluble-ion analysis were cut at $5 \mathrm{~cm}$ intervals, resulting in 630 samples. For each cut section, the outer portion ( $\sim 1 \mathrm{~cm}$ thickness) was removed with a pre-cleaned stainless-steel scalpel for $\delta^{18} \mathrm{O}$ analysis, and the inner portion was separated for ionic analysis. Sample processing was performed in a cold $\left(-20^{\circ} \mathrm{C}\right)$, class 100 clean room and samples were allowed to melt in sealed vials at room temperature immediately prior to isotopic analysis.

Oxygen isotope ratios were determined at the Key Laboratory of Tibetan Environment Changes and Land Surface Processes, Chinese Academy of Sciences, using a continuous-flow isotope ratio mass spectrometry system with similar referencing strategies to those described by Werner and Brand (2001). Sample vials were auto-flush-filled with $0.3 \% \mathrm{CO}_{2}$ in $\mathrm{He}$ and analyzed after equilibration with a Finnigan Delta ${ }^{\text {plus }}$ MAT 253 isotope ratio mass spectrometer (IRMS) and GasBench II/GC PAL system. Care was taken to avoid possible contamination that can result from insufficient flush-fill time or extended storage (Paul and Skrzypek, 2006). Sample isotope ratios are reported as the average of five peaks per sample using the standard delta notation $(\delta)$ versus Vienna Standard Mean Ocean Water (V-SMOW). Analytical $\delta^{18} \mathrm{O}$ precision was $0.09 \%$ o $(n=630)$ based on maximum deviation of external standards for all runs.

Deuterium $(\delta \mathrm{D})$ analysis was performed at the Institute of Tibetan Plateau Research, Lhasa branch, by continuous-flow isotope ratio mass spectrometry using a Finnigan Delta ${ }^{\text {plus }}$ system. Water samples of $1 \mathrm{~mL}$ volume were completely vaporized, with a platinum catalyst used to actuate the exchange reaction. Helium is used for the carrier gas, which constantly flushes the equilibration chamber, after which the gas is dried and injected into the IRMS. Analytical principles, procedures and corrections are described in detail by Huber and Leuenberger (2003). $\delta$ D analytical precision, also based on the maximum deviation of external standards, was $<1.5 \%$ o $(n=630)$. Analytical uncertainty of d-excess is calculated from the quadratic average of the uncertainty for $\delta \mathrm{D}$ and $8 \cdot \delta^{18} \mathrm{O}$ (Fröhlich and others, 2002), here $\sim 1.52 \%$.

Core depth-age scale was established via annual-layer counting of major-ion peaks, as $\delta^{18} \mathrm{O}$ isotope values did not exhibit discernible annual peaks due to insufficient winter accumulation (Joswiak and others, 2010). Annual peaks in ion concentrations were apparent due to both wet and dry deposition. During the cold dry winter and spring, dust deposition results in higher major-ion concentrations in the ice-core layers, while wet deposition preserves relatively lower ion concentrations during the summer. Therefore, annual identification was achieved using peak concentrations of $\mathrm{SO}_{4}{ }^{2-}$ and $\mathrm{Ca}^{2+}$ to the full core depth as previously described by Zheng and others (2010). Annual average values are reported as the precipitation-weighted mean, considering the variable number of samples associated with each annual layer.

Meteorological data from five of the closest ground-based stations to the drill site (Wudaoliang, Tuotuohe, Bange, Amdo and Nagqu) were used for comparison with the stable-isotope data. Surface data from China's National Climate Data Center Global Summary of the Day (GSOD) were used to obtain monthly, annual average and 5 year running mean temperature and precipitation. Station locations are shown in Figure 1; coordinates, elevation, period of record, annual precipitation and temperature are summarized in Table 1. Although these are the nearest ground-based stations, distances from the drill site are substantial. The closest stations to the ice-core drill site are Tuotuohe and Amdo, located $150 \mathrm{~km}$ to the northeast and southeast, respectively. Naqu station is located $180 \mathrm{~km}$ to the south, Wudaoliang is $250 \mathrm{~km}$ to the northeast and Bange station is $275 \mathrm{~km}$ to the southwest (Fig. 1). Monsoon season (JuneSeptember) northern India rainfall data for 1850-2004 are from Sontakke and others (2008). The coverage region for the northern India total rainfall is shown as the hatched region in Figure 1. Climate indices used for comparison included the North Atlantic Oscillation (NAO) index, which may indicate relative strength of the prevailing westerlies. The Southern Oscillation (SO) index, which is tightly coupled with the south Asian monsoon (Krishnamurthy and Goswami, 2000), was also compared with the ice-core isotopic data. Both the NAO and SO indices were obtained from the Climatic Research Unit, University of East Anglia, UK (http://www.cru.uea.ac.uk/). 
Owing to the previously documented relationship between Pacific SSTs and $\delta^{18} \mathrm{O}$ in Himalayan and central Asian ice cores (Bradley and others, 2003; Zhang and others, 2012), we investigated this relationship at the TGL05 core site by comparing annual isotope values with the NINO3.4 index of Pacific SST (Trenberth and Stepaniak, 2001). Considering the documented relationship between monsoon rainfall and Indian Ocean surface temperatures (Ashok and Guan, 2004; Kripalani and Kumar, 2004), ice-core isotope values were also compared with the Dipole Mode index (DMI). DMI data were provided by the Climate Variation Predictability and Applicability Research Program, Research Institute for Global Change, Japan Agency for Marine-Earth Science and Technology (http://www.jamstec.go.jp).

Given the significant lag-1 autocorrelation coefficient for the 5 year averaged data, significance tests were performed using an effective degrees of freedom $\left(n^{*}\right)$ calculated by scaling the number of observations by a factor of $\left(1-r_{i}\right) /$ $\left(1+r_{i}\right)$, where $r_{i}$ is the autocorrelation coefficient (Bretherton and others, 1999). Statistical significance is based on the 95\% confidence interval convention $(\alpha=0.05)$.

\section{RESULTS AND DISCUSSION}

\subsection{Ice-core dating and accumulation}

Annual-layer counting was possible to the full $33 \mathrm{~m}$ ice-core depth, resulting in 155 annual layers covering 1850-2004. Two peaks in $\beta$-activity were found at depths of 11.3 and $13.4 \mathrm{~m}$, corresponding to the 1963 and 1954 nuclear tests, respectively, and were used as reference horizons for dating (Zheng and others, 2010). Layer-counted dating was within \pm 1 year of the reference horizons of maximum $\beta$-activity. Accuracy of the 1850 bottom depth is estimated at \pm 5 years based on comparison with flow-modeled depth (Nye, 1963), since absolute-dated horizons below $13.4 \mathrm{~m}$ depth are not available for direct comparison. Relative concentrations of major ions are lower (by $\sim 25-50 \%$ ) in some portions of the lower core, although peaks are still identifiable when examined at the appropriate scale. To reduce uncertainty associated with identification of specific years, we report mainly long-term trends and decadal averages.

Temperature data at the drill site elevation are not available, although we may estimate an annual average temperature based on previously published results. Fujita and Ageta (2000) measured temperature over a 1 year period on Xiao Dongkemadi glacier $\sim 5 \mathrm{~km}$ south of the TGL05 drill site. For October 1992-October 1993, the annual average temperature at $5600 \mathrm{~m}$ a.s.I. was $-10.3^{\circ} \mathrm{C}$. If we apply a local lapse rate of $0.0075^{\circ} \mathrm{C} \mathrm{m}^{-1}$ (Ohata and Ageta, 1996), we can estimate an annual average temperature at the drill site elevation of $-11.4^{\circ} \mathrm{C}$. Using a 1 year temperature record from the Tanggula pass (4990 ma.s.l.) located $\sim 190 \mathrm{~km}$ to the west in conjunction with the same lapse rate, results in a similar annual average temperature estimate. Zhang and others (1994) reported an annual average temperature from a station near the Tanggula pass (4990 ma.s.l.) of $-6.0^{\circ} \mathrm{C}$ for a 1 year period (November 1989-October 1990). If we apply the same local lapse rate, we obtain an annual average temperature of $-11.6^{\circ} \mathrm{C}$ at the TGL05 drill site elevation. These annual average temperature estimates are lower than the TGL05 $10 \mathrm{~m}$ borehole temperature of $-7.2^{\circ} \mathrm{C}$ reported by Zheng and others (2010). Results are consistent with a previous study of borehole temperatures for alpine glaciers in central Asia, which reported $10 \mathrm{~m}$ ice temperatures to be
$3-4{ }^{\circ} \mathrm{C}$ higher than annual average surface temperatures (Liu and others, 2009).

At the upper accumulation drill site, only a thin $(<1 \mathrm{~m})$ firn pack overlies the glacier ice. Owing to the low annual accumulation and high density of the glacier ice throughout the core, visual identification and measurement of melt layers to quantify melt percent is not possible. Limited impact of melt on the ice-core isotope and ion profiles is evidenced by the well-preserved peaks in ion concentrations coincident with the highest temperatures of the 20th century (Joswiak and others, 2010). In addition, previous results from the TGL05 core revealed that the site is within the upper accumulation zone with negligible meltwater percolation (Zheng and others, 2010). To further illustrate the minimal impact of melt on the TGL05 ice-core geochemical record, we investigated possible preferential elution of ions, which has been established for melting snow both in the laboratory and in the field. Previous studies have reported $\mathrm{SO}_{4}{ }^{2-}$ and $\mathrm{NO}_{3}{ }^{-}$exhibit preferential elution in comparison with $\mathrm{Na}^{+}$ and $\mathrm{Cl}^{-}$, which are preferentially held back in melting snow (Davies and others, 1982; Tsiouris and others, 1985). This difference may result in an offset of $\mathrm{SO}_{4}{ }^{2-}$ and $\mathrm{NO}_{3}{ }^{-}$peak concentrations, compared with $\mathrm{Na}^{+}$and $\mathrm{Cl}^{-}$. The most recent 5 year period, 2000-04, was selected for comparison of the variability of these four major ions, as this period recorded the highest annual average June-September temperatures $\left(6.5^{\circ} \mathrm{C}\right.$; Fig. $4 \mathrm{e}$, further below) and may therefore be expected to have the greatest possible impact on seasonal melting. As illustrated in Figure 3, all the aforementioned ions show consistent peak concentrations within the uppermost core portion, providing further evidence of minimal melt impact on the TGL05 ice-core geochemistry.

Average net annual accumulation for 1850-2004 was $293 \mathrm{~mm}$ w.e. $\mathrm{a}^{-1}$ calculated by methods outlined by Haefeli (1961) and Henderson and others (2006), which uses the ratio of the annual layer thickness to the flow-modeled thickness (Nye, 1963) multiplied by the surface accumulation rate. Annual accumulation generally decreased until 1950, then increased until the mid- to late 1980s before decreasing again (Fig. 4a). The period prior to the 1930s revealed both higher annual accumulation and greater intraannual variability (Fig. 4a). No statistically significant linear trend in accumulation was present for 1850-2005. In comparison with the TGL05 ice core presented here, the Puruogangri ice core from the central TP revealed a higher accumulation rate of $440 \mathrm{~mm} \mathrm{a}^{-1}$ for 1965-2000 (Yao and others, 2008). Puruogangri is located $\sim 280 \mathrm{~km}$ from the TGL05 drill site (Fig. 1). In general, ice cores from the northern TP (e.g. Dunde and Guliya) exhibit increasing accumulation during the 20th century, while ice cores from the southern TP (e.g. Dasuopu, East Rongbuk) exhibit decreasing accumulation (Hou and others, 2002; Yao and others, 2008). TGL05 annual accumulation was not significantly correlated with annual precipitation data from any of the five nearest ground-based meteorological stations, likely resulting from the distance between the ice-core site and the nearest meteorological stations $(150 \mathrm{~km})$ as well as the elevation difference $(\geq 1000 \mathrm{~m})$. In addition, orographic effects may contribute to greater spatial variability of convective moisture (Anders and others, 2006).

Extreme amounts of isotopically depleted precipitation are prevalent during the time of maximum monsoon precipitation in monsoon-dominated regions of the southern TP, manifested as a significant negative correlation between 
Table 2. Stable-isotope summary statistics for the upper core (depth range $0.05-13.28 \mathrm{~m}$ w.e., 1942-2004), the lower core (depth range 14.64-28.26 m w.e., 1850-1934) and the full core data. All values are per mil $(\%)$

\begin{tabular}{lcrrrr}
\hline & & Max. & Min. & Mean & Std dev. \\
\hline Upper core & $\delta^{18} \mathrm{O}$ & -8.4 & -18.1 & -13.0 & 1.8 \\
$n=279$ & $\delta \mathrm{D}$ & -48.1 & -133.6 & -87.3 & 15.3 \\
& $\mathrm{~d}$-excess & 24.7 & 6.6 & 16.5 & 2.5 \\
Lower core & $\delta^{18} \mathrm{O}$ & -7.5 & -18.7 & -14.3 & 1.7 \\
$n=303$ & $\delta \mathrm{D}$ & -41.2 & -127.4 & -94.5 & 13.3 \\
& $\mathrm{~d}-$-excess & 26.3 & 13.6 & 19.8 & 2.1 \\
Overall & $\delta^{18} \mathrm{O}$ & -7.5 & -18.7 & -13.7 & 1.9 \\
$n=612$ & $\delta \mathrm{D}$ & -41.2 & -133.6 & -91.0 & 14.5 \\
& $\mathrm{~d}$-excess & 26.3 & 6.6 & 18.2 & 2.8 \\
\hline
\end{tabular}

accumulation and oxygen-18 values. The TGL05 core revealed no significant negative correlation between annual accumulation and annual average isotope values. In addition, no correlation between temperature and accumulation was observed. Annual accumulation was also compared with climate data for two periods of significantly different mean d-excess values (Section 3.2). The period of relatively lower d-excess values subsequent to the 1940s did not reveal a significant relationship with the SO index. The period of relatively higher d-excess values prior to 1934 (Fig. 4c) revealed a positive correlation $(r=0.20)$, although not statistically significant, between annual accumulation and the NAO index. Correlation between accumulation and the NAO in the upper core portion was lower $(r=0.11)$, suggesting an enhanced contribution from westerly-dominated moisture sources in the lower core with higher d-excess values. The association of westerly wind strength with the NAO index was evaluated using US National Centers for Environmental Prediction/US National Center for Atmospheric Research (NCEP/NCAR) reanalysis data (Kalnay and others, 1996). The difference in the vector wind composite mean between the highest NAO index year (1961) and the lowest NAO index year (1993) indicates positive northwesterly winds in the central TP (Fig. 5).

\subsection{Stable-isotope variability, comparison with climate data and indices}

Annual average isotope values for the TGL05 ice core exhibit distinctive characteristics. Overall, $\delta^{18} \mathrm{O}$ is slightly more depleted compared with the nearby Geladaindong ice core (Kang and others, 2007; Zhang and others, 2007; Joswiak and others, 2010), which is located $100 \mathrm{~km}$ from the TGL05 drill site (Fig. 1). Summary statistics for $\delta^{18} \mathrm{O}, \delta \mathrm{D}$ and $\mathrm{d}$ excess are presented in Table 2. Annual $\delta^{18} \mathrm{O}$ values (Fig. 4b) reveal an increasing linear trend for 1850-2004, which is statistically significant. Periods of notable increase in annual $\delta^{18} \mathrm{O}$ were observed for 1881-94 and 1994-2004. There are also periods of annual $\delta^{18} \mathrm{O}$ decrease, most notably $1900-10$ and 1914-33. In contrast to the general increasing trend of $\delta^{18} \mathrm{O}$, the annual average $\mathrm{d}$-excess values show a significant decreasing trend over the entire period represented (Fig. 4c). However, rather than a steady decrease, annual d-excess values show no significant trend within two sections of higher and lower d-excess values, shown as the two separate trend lines in Figure 4c. For 1850-1934 (the lower core

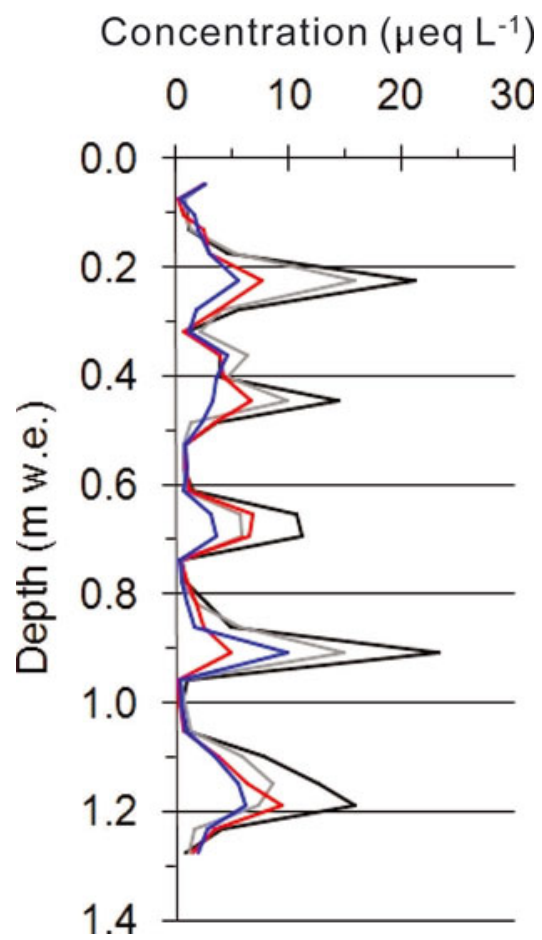

Fig. 3. Major-ion peaks in the TGL05 ice core for the most recent 5 years (2000-04). No preferential elution is evident from the consistent peak concentrations among sulfate (black), nitrate (grey), sodium (red) and chloride (blue).

portion), average annual d-excess is $19.8 \%$, with annual values as high as 26.3\%. For 1942-2004 (the upper core portion), average annual d-excess is $16.5 \%$. Results of a twosample $t$ test assuming equal variances indicate the differences in mean d-excess values for the two time periods are statistically significant. Annual values as low as $6.6 \%$ in the upper core portion result in an overall annual range of $19.7 \%$ (Table 2). The two time periods are separated by a general decrease in annual d-excess from 1935 to 1941, during which time average values decrease from $22.0 \%$ to 17.2\% (Fig. 4c).

Previous results from the TGL05 ice core indicated no significant correlation among annual isotope values and June-September average temperatures for 1958-2003 (Joswiak and others, 2010). As illustrated in Figure $4, \delta^{18} \mathrm{O}$ variability (Fig. 4b) is not consistent with the temperature variability recorded at Tuotuohe station (Fig. 4e). Annual average $\delta^{18} \mathrm{O}$ values revealed no significant correlation with June-September temperatures measured at the five meteorological stations, even over 5 year moving averages (Table 3 ). The substantial distance between the ice-core drill site and meteorological stations as well as the elevation differences must also be considered when interpreting the isotopetemperature relationships. Annual average d-excess data do reveal a negative correlation for the three nearest meteorological stations (Tuotuohe, Amdo, Naqu) and for the average temperature calculated from all five stations (Table 3). Owing to the large reduction in effective degrees of freedom associated with the 5 year moving averages, the negative correlations are not statistically significant. It should be emphasized that the physical basis for the relationship of d-excess with temperature differs from that with oxygen-18. As outlined in Section 1, oxygen-18 alone typically reflects the sub-cloud temperature during moisture condensation, 


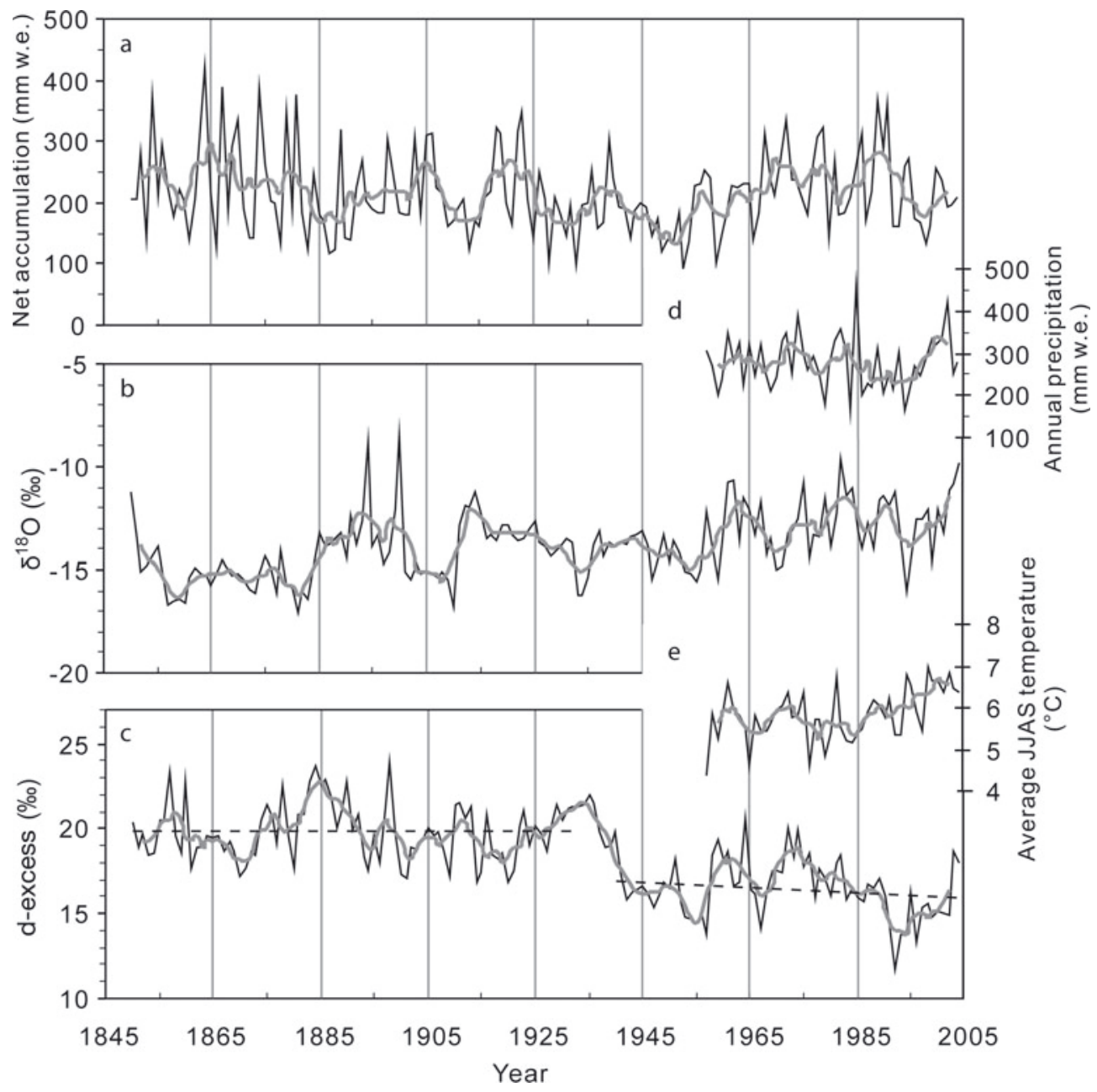

Fig. 4. Annual net accumulation (a) and annual average isotope variability for the TGL05 ice core (0.05-28.26 m w.e. depth). Oxygen isotope values (b) and d-excess (c) are shown with Tuotuohe station precipitation (d) and average June-September (JJAS) air temperature (e). Annual averages are indicated in black; 5 year moving averages are shown in gray. Dashed lines in (c) indicate linear trend for the upper and lower core portions.

while the second-order parameter of d-excess mainly records evaporative water source temperature and humidity conditions. Accordingly, negative correlations among d-excess and temperature have not been previously reported in ice cores. At the TGL05 core site, this relationship may be associated with a change in the contribution of continentalevaporated and marine-evaporated moisture coincident with annual temperature variations.

Previous results of oxygen-18 variability in the TGL05 core revealed a significant negative correlation with the amount of northern India precipitation. As reported by Joswiak and others (2010), greater annual isotope depletion corresponds well with greater annual northern India precipitation, using data from Sontakke and others (2008) for 19352004. However, when analyzing oxygen-18 data to the full core depth of $33 \mathrm{~m}$, it is apparent that the negative correlation does not persist throughout the period 18501934. Rather than a significant negative correlation, the earlier period revealed a slight positive correlation, although insignificant at the $\alpha=0.05$ level. These results indicate the previously reported relationship between annual $\delta^{18} \mathrm{O}$ values and northern India monsoon precipitation is not temporally consistent or stable over a longer time period.

The NAO index was also examined in conjunction with the TGL05 isotope records. Previous results from the Malan ice core in the northern TP $(\sim 330 \mathrm{~km}$ from the TGL05 ice core; Fig. 1) revealed significant correlation between $\delta^{18} \mathrm{O}$ values and the May-October NAO index for 1887-1998 (Wang and others, 2003b). Annual $\delta^{18} \mathrm{O}$ and d-excess variability in the TGL05 ice core was compared with the NAO index (May-October), with no significant correlation observed (Table 4). The SO index did reveal a significant negative correlation with annual average $\delta^{18} \mathrm{O}$ values in the TGL05 ice core (Table 4), providing further evidence of

Table 3. Correlation coefficients between average June-September station temperatures, $\delta{ }^{18} \mathrm{O}$ and d-excess. No values were significant at the $\alpha=0.05$ level

\begin{tabular}{lcrrrr}
\hline & & \multicolumn{2}{c}{$\delta^{18} \mathrm{O}$} & \multicolumn{2}{c}{ d-excess } \\
& \multicolumn{1}{c}{ Period } & Annual & 5 year & Annual 5 year \\
& & & & & \\
\hline Wudaoliang & $1957-2004$ & 0.11 & -0.06 & -0.08 & -0.14 \\
Tuotuohe & $1957-2004$ & 0.07 & -0.09 & 0.04 & -0.36 \\
Bange & $1957-2004$ & 0.02 & 0.09 & 0.08 & -0.14 \\
Amdo & $1966-2004$ & -0.04 & -0.15 & -0.04 & -0.49 \\
Naqu & $1955-2004$ & 0.16 & 0.16 & -0.17 & -0.62 \\
Five-station average & $1966-2004$ & 0.07 & -0.04 & -0.08 & -0.50
\end{tabular}




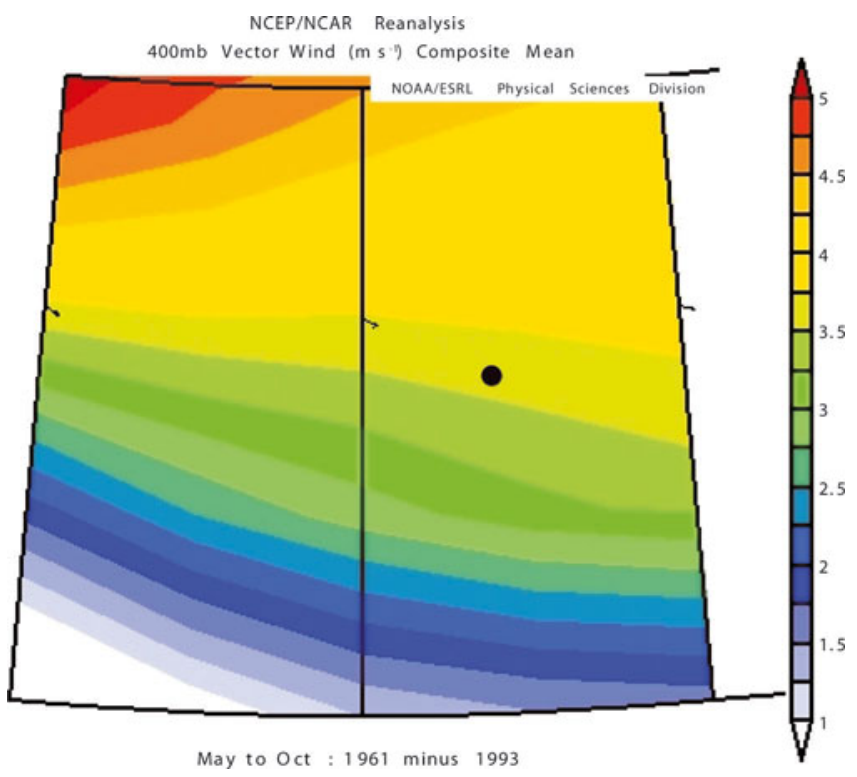

Fig. 5. Difference in the vector wind composite mean between the highest and lowest NAO index years for the region $30-36^{\circ} \mathrm{N}$, $85-95^{\circ}$ E. Black dot shows the approximate location of the TGL05 ice core. Image provided by the Physical Sciences Division of the Earth and Space Research Laboratory of the National Oceanic and Atmospheric Administration (NOAA/ESRL), Boulder, CO, USA (http://www.esrl.noaa.gov/psd/).

monsoon influence on the isotopic signals at this study location. The SO index also revealed a significant correlation $(r=0.53)$ with the amount of northern India precipitation, supporting the relationship between the SO index and monsoon strength. Annual average $\delta^{18} \mathrm{O}$ values also revealed a significant positive correlation with the NINO3.4 index and the DMI, while d-excess values revealed a significant negative correlation with the DMI (Table 4).

Previous studies have indicated a negative relationship between local relative humidity and d-excess (Merlivat and Jouzel, 1979; Naik and others, 2010), although this relationship does not adequately explain the influence of relative humidity at the source region where the moisture was evaporated (Naik and others, 2010). To investigate this possible relationship in the TGL05 ice core, annual d-excess values were compared with local station relative humidity (June-September) calculated from the GSOD data. No significant correlation was observed between annual $\mathrm{d}$-excess values and relative humidity, supporting the major influence of moisture source conditions on the annual $\mathrm{d}$-excess values. Average d-excess values were clustered in two periods of relatively higher and lower annual average values, 1850-1934 and 1942-2004, respectively (Table 2; Fig. 4c). Annual d-excess values revealed no significant trend within each of the two higher and lower periods, shown by the dotted lines in Figure 4c. The changes in both the $\delta^{18} \mathrm{O}-$ monsoon precipitation relationship and the d-excess shift at a consistent time period in the late 1930s suggest distinct moisture source differences at this study location between the two periods 1850-1934 and 1942-2004.

\subsection{Deuterium excess, local meteoric waterlines and moisture recycling}

With both oxygen-18 and deuterium analysis available, it is possible to examine the linear correlation among the two stable isotopes in comparison with the GMWL
Table 4. Correlation coefficients between TGL05 ice-core isotopes, climate indices and northern India precipitation. Numbers in bold indicate significance at the $\alpha=0.05$ level

\begin{tabular}{lrrrrrr}
\hline & & \multicolumn{2}{c}{$\delta^{18} \mathrm{O}$} & \multicolumn{2}{c}{$\mathrm{d}$-excess } \\
& Period & Annual & 5 year & Annual 5 year \\
& & & & & \\
\hline NAO (May-Oct) & $1850-2004$ & 0.03 & -0.04 & 0.11 & 0.27 \\
SO (Aug-Nov) & $1866-2004$ & $\mathbf{- 0 . 1 8}$ & -0.31 & 0.07 & 0.12 \\
NINO3.4 & $1871-2004$ & $\mathbf{0 . 2 2}$ & 0.20 & -0.08 & 0.18 \\
DMI & $1871-2004$ & $\mathbf{0 . 2 0}$ & 0.34 & $\mathbf{- 0 . 2 6}$ & 0.48 \\
Northern India & $1850-2004$ & -0.12 & -0.22 & 0.07 & 0.27 \\
precipitation (Jun-Sept) & & & & &
\end{tabular}

$\left(\delta \mathrm{D}=8 \cdot \delta^{18} \mathrm{O}+10 ;\right.$ Craig, 1961). This relationship has been previously studied and defined as an LMWL at many locations around the Earth. Figure 6 shows the LMWLs for the entire core (Fig. 6a) and for each of the two periods of interest: 1942-2004 (Fig. 6b) and 1850-1934 (Fig. 6c). In comparison with the GMWL, the earlier period with overall higher d-excess values (Fig. 6c) has a slightly greater waterline slope. The later period 1942-2004 has a slightly lower slope compared with the GMWL (Fig. 6b), although both waterline slopes (8.2 and 7.7) are quite close to the GMWL slope of 8.0. Nearly all data points plot above the GMWL, an indication of precipitation at low temperature with low absolute moisture content of the air (Pang and others, 2011). It is also noted that the upper core portion, with relatively lower d-excess values, has generally lower $\delta^{18} \mathrm{O}$ values (mean of $-13.0 \%$ o compared with $-14.3 \%$ in the lower core; Table 2).

The overall average annual d-excess in the TGL05 ice core of $18.2 \%$ indicates a large contribution from continental recycling. High d-excess values associated with westerly or northern transport of cold dry moisture with a significant contribution from local recycled moisture were reported previously for central TP precipitation (Liu and others, 2008). Few long-term records of d-excess exist for ice cores from the TP. A 1000 year ice-core record from Dasuopu $(800 \mathrm{~km}$ southwest of the TGL05 drill site; Fig. 1) in the southern TP reveals comparatively lower d-excess values ( 10-15\%) associated with significant monsoon moisture contributions (Thompson and others, 2000). Another ice-core record from the southern TP reported a similarly low average d-excess value of $12.3 \%$ for the period $1864-2006$, also due to the primary contribution of monsoon precipitation (Zhao and others, 2012). Records of d-excess variability in ice cores also exist for regions in central Asia, where high d-excess values in the Pamirs $(\sim 18 \%)$ and even higher in the Tien Shan $(>22 \%$ ) are associated with significant contributions from continental recycled moisture (Kreutz and others, 2003; Aizen and others, 2009).

The d-excess values in precipitation are mainly controlled by conditions during moisture evaporation, especially the moisture deficit above where the local moisture evaporated (Merlivat and Coantic, 1975). Local moisture evaporation from the extensive lakes in the central TP is under dryer conditions than from southern oceanic sources. This difference leads to higher d-excess values in precipitation from local evaporated moisture, and comparatively lower d-excess values associated with moisture from the warmer, more humid oceanic sources south of the TP. This was previously observed for precipitation in the central TP (Tian 
and others, 2001a) and we therefore infer a relatively greater contribution from locally evaporated moisture for 1850 1934 with relatively higher average annual d-excess values. Results suggest an increase in the contribution of warmer moisture sources since the early 1940s, with a comparatively lower d-excess average of $16.5 \%$ or that period.

\subsection{Discussion}

Stable isotopes in the TGL05 ice core mainly preserve information related to moisture source, which is strongly coupled with temperature variability. The higher $\delta^{18} \mathrm{O}$ values in the upper core coincide with local temperature increase, but the magnitude of increase is inconsistent with increasing temperature, especially since the 1940s. At the TGL05 icecore site, the influx of depleted monsoon moisture to the central TP may be responsible for a dampening effect on the $\delta^{18} \mathrm{O}$ temperature signal, which increases less dramatically compared with local and regional temperatures. $\delta^{18} \mathrm{O}$ values are correlated with the NINO3.4 index, consistent with previous results for an ice core from the central Himalaya (Bradley and others, 2003). A negative correlation between d-excess and DMI values may be related to enhanced transport of moisture associated with the westward shift of the Indian Ocean warm pool. The prolonged differences in the tropical western Pacific air surface pressure associated with the El Niño Southern Oscillation (ENSO) are coupled with monsoon circulation and Indian monsoon rainfall (Krishnamurthy and Goswami, 2000).

Although not statistically significant, the negative correlations between $d$-excess and station temperature may illustrate the coupling of moisture source and temperature in the study region. Since high d-excess values are associated with a greater contribution of continental recycled moisture, it is likely that the contribution of westerly or northern moisture may be greater during colder years, during which time the westerly jet and Siberian highpressure systems are pushed further south. During relatively warmer years, south Asian monsoon moisture may penetrate further into the central TP, resulting in relatively low annual d-excess. Results are consistent with previous studies suggesting enhanced monsoon circulation during the 20th century based on modeling results (Meehl and Washington, 1993; Uchijima and Ohta, 1996), dendrochronology (Bräuning and Mantwill, 2004) and Arabian Sea fossil abundances (Anderson and others, 2002).

In addition to annual moisture source variability, the seasonal accumulation variability may also be impacting the isotope record at this study location. Although in a region of dominantly warm-season accumulation, the ice-core isotope values may still preserve some cold-season signal, especially in years with relatively more winter snowfall. However, owing to the low annual accumulation, resolving seasonal signals is not realistic at the $5 \mathrm{~cm}$ sampling resolution.

The period of relatively low d-excess since the 1940s corresponds to the time period of significant anticorrelation between annual $\delta^{18} \mathrm{O}$ and northern India precipitation. This is consistent with the notion of an increased contribution of south Asian monsoon moisture during that time, which could bring relatively lower d-excess values and also be responsible for the negative correlation between $\delta^{18} \mathrm{O}$ and northern India precipitation. Previous results indicated a period of generally negative DMI values associated with the years 1880-1920 and a period of generally positive DMI values during 1960-2000 (Kripalani and Kumar, 2004). a

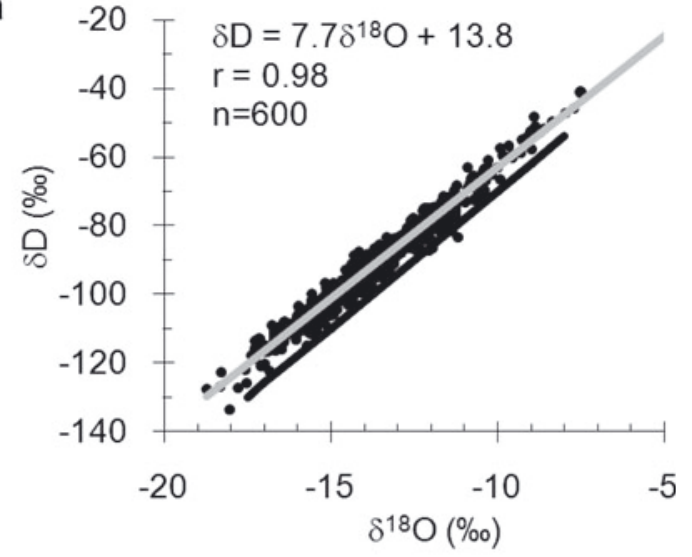

b
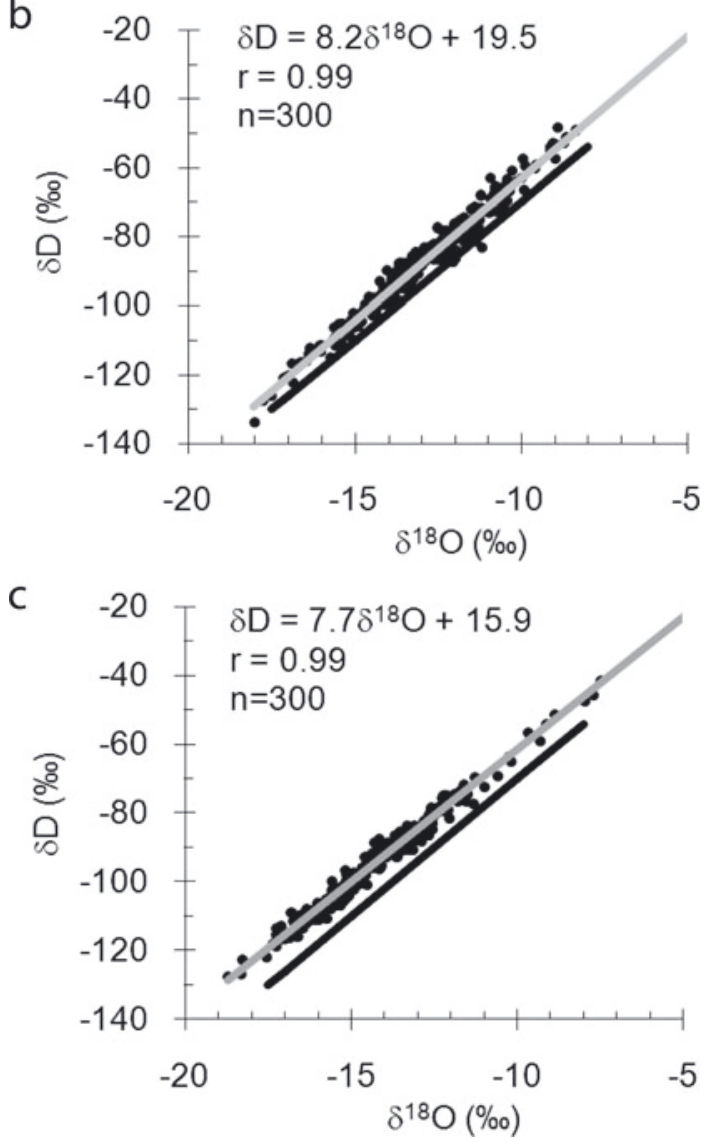

Fig. 6. $\delta^{18} \mathrm{O}-\delta \mathrm{D}$ linear correlation (meteoric waterlines) for the full core data (a), the upper core (b) and the lower core (c). GMWL shown in black for comparison.

These periods of generally negative and positive DMI values are within the periods of higher and lower ice-core d-excess values, respectively, which is consistent with the significant negative correlation between $d$-excess and the DMI (Table 4). The lack of correlation between ice-core accumulation and northern India precipitation indicates monsoon moisture is not contributing significantly to the amount of accumulation at the ice-core site. However, results suggest a southerly monsoon moisture source is impacting the preserved isotopic signal. During the period of higher d-excess values (1850-1934), no significant correlation is observed between oxygen-18 and northern India precipitation. Results suggest an increase in the contribution of moisture evaporated under more humid conditions to the central TP since the 1940s. 


\section{CONCLUSIONS}

These results expand the spatial coverage of isotope proxy records over the TP. The TGL05 ice core reveals wellpreserved stable-isotope variability for 1850-2004. Although previous results showed a significant negative correlation between $\delta^{18} \mathrm{O}$ and northern India precipitation, the correlation does not hold for the period prior to the 1940s (1850-1934). Two distinct periods of d-excess values are noted, one with higher values (1850-1934) and one with lower values (1942-2004). The lack of correlation between $\delta^{18} \mathrm{O}$ and northern India temperature coincides with a period of significantly higher d-excess, suggesting westerlydominated moisture may have made a relatively greater contribution to ice-core accumulation during that time. The periods are separated by a transition period of sharply decreasing d-excess. A decreased contribution of local recycled moisture in the central TP since the latter half of the 20th century is inferred from the d-excess record, with generally lower average values since the early 1940s. However, we infer an overall high contribution of local evaporated moisture at the study location based on the high $\mathrm{d}$-excess values throughout the ice-core record.

Stable isotopes at this location preserve information related to the interaction of a number of parameters including temperature effects, monsoon moisture impacts, differences in climatic conditions in the moisture source regions and contributions from local evaporated moisture sources. In addition, the relationship between annual $\delta^{18} \mathrm{O}$ values and the $\mathrm{SO}$ index suggests an impact of monsoon moisture on the isotope record, while high d-excess values and the relationship with the NAO demonstrate the importance of westerly and continental recycled moisture in the central TP. Annual average $\delta^{18} \mathrm{O}$ values were also significantly correlated with the NINO3.4 index and with the DMI. Ice-core $d$-excess values revealed a significant negative correlation with DMI values, offering promise for further use of the d-excess parameter in investigating moisture transport and sources. However, reconstruction of single climate parameters or indices, such as temperature, precipitation and oceanic or atmospheric indices, is unlikely from ice cores within this special boundary location between westerly- and monsoon-dominated moisture sources.

\section{ACKNOWLEDGEMENTS}

This research was supported by the Chinese Academy of Sciences/State Administration of Foreign Expert Affairs (CAS/ SAFEA) International Partnership Program for Creative Research Teams (KZCX2-YW-T11), the External Cooperation Program of the Chinese Academy of Sciences (GJHZ0960) and the Natural Science Foundation of China (NSFC) project 40830638.

\section{REFERENCES}

Aizen VB, Aizen E, Fujita K, Nikitin SA, Kreutz KJ and Takeuchi N (2005) Stable-isotope time series and precipitation origin from firn-core and snow samples, Altai Glaciers, Siberia. J. Glaciol., 51(175), 637-654 (doi: 10.3189/172756505781829034)

Aizen VB and 9 others (2009) Stable-isotope and trace element time series from Fedchenko Glacier (Pamirs) snow/ firn cores. J. Glaciol., 55(190), 275-291 (doi: 10.3189/ 002214309788608787)
Anders AM, Roe GH, Hallet B, Montgomery DR, Finnegan NJ and Putkonen J (2006) Spatial patterns of precipitation and topography in the Himalaya. In Willett SD, Hovius N, Brandon MT and Fisher DM eds. Tectonics, climate, and landscape evolution (Special Paper 398) Geological Society of America, Boulder, CO

Anderson DM, Overpeck JT and Gupta AK (2002) Increase in the Asian southwest monsoon during the past four centuries. Science, 297(5581), 596-599 (doi: 10.1126/science.1072881)

Araguás-Araguás L, Froelich K and Rozanski K (1998) Stable isotope composition of precipitation over southeast Asia. J. Geophys. Res., 103(D22), $28721-28742$ (doi: 10.1029/98JD02582)

Ashok K and Guan Z (2004) Individual and combined influences of ENSO and the Indian Ocean dipole on the Indian summer monsoon. J. Climate, 17(16), 3141-3155 (doi: 10.1175/15200442(2004)017<3141:IACIOE>2.0.CO;2)

Bradley RS, Vuille M, Hardy D and Thompson LG (2003) Low latitude ice cores record Pacific sea surface temperatures. Geophys. Res. Lett., 30(4), 1174 (doi: 10.1029/2002GL016546)

Bräuning A and Mantwill B (2004) Summer temperature and summer monsoon history on the Tibetan plateau during the last 400 years recorded by tree rings. Geophys. Res. Lett., 31(24), L24205 (doi: 10.1029/2004GL020793)

Bretherton CS, Widmann M, Dymnikov VP, Wallace JM and Bladé I (1999) The effective number of spatial degrees of freedom of a time-varying field. J. Climate, 12(7), 1990-2009 (doi: 10.1175/ 1520-0442(1999)012<1990:TENOSD >2.0.CO;2)

Craig H (1961) Isotopic variations in meteoric waters. Science, 133(3465), 1702-1703 (doi: 10.1126/science.133.3465.1702)

Dansgaard W (1964) Stable isotopes in precipitation. Tellus, 16(4), 436-468

Davies TD, Vincent CE and Brimblecombe P (1982) Preferential elution of strong acids from a Norwegian ice cap. Nature, 300(5888), 161-163 (doi: 10.1038/300161a0)

Fröhlich K, Gibson JJ and Aggarwal PK (2002) Deuterium excess in precipitation and its climatological significance. In Study of Environmental Change Using Isotope Techniques, Proceedings of an International Conference, 23-27 April 2001, Vienna, Austria (C\&S Papers Series 13) International Atomic Energy Agency, Vienna, 54-65

Fujita K and Ageta Y (2000) Effect of summer accumulation on glacier mass balance on the Tibetan Plateau revealed by massbalance model. J. Glaciol., 46(153), 244-252 (doi: 10.3189/ 172756500781832945)

Gat JR (1996) Oxygen and hydrogen isotopes in the hydrologic cycle. Ann. Rev. Earth Planet. Sci., 24, 225-262.

Gat JR, Bowser CJ, Kendal K (1994) The contribution of evaporation from the Great Lakes to the continental atmosphere: estimate based on stable isotope data. Geophys. Res. Lett., 21(7), 557-560 (doi: 10.1029/94GL00069)

Haefeli R (1961) Contribution to the movement and the form of ice sheets in the Arctic and Antarctic. J. Glaciol., 3(30), 1133-1151

Henderson K, Laube A, Gäggeler HW, Olivier S, Papina T and Schwikowski M (2006) Temporal variations of accumulation and temperature during the past two centuries from Belukha ice core, Siberian Altai. J. Geophys. Res., 111(D3), D03104 (doi: 10.1029/2005JD005819)

Henderson-Sellers A, McGuffie K, Noone D and Irannejad P (2004) Using stable water isotopes to evaluate basin-scale simulations of surface water budgets. J. Hydromet., 5(5), 805-822 (doi: 10.1175/1525-7541(2004)005<0805:USWITE>2.0.CO;2)

Hou S, Qin D, Yao T, Zhang D and Chen T (2002) Recent change of the ice core accumulation rates on the Qinghai-Tibetan Plateau. Chinese Sci. Bull., 7(20), 1746-1749 (doi: 10.1007/BF03183321)

Huber C and Leuenberger M (2003) Fast high-precision on-line determination of hydrogen isotope ratios of water or ice by continuous-flow isotope ratio mass spectrometry. Rapid Commun. Mass Spectrom., 17(12), 1319-1325 (doi: 10.1002/rcm.1055)

Joswiak DR, Yao T, Wu G, Xu B and Zheng W (2010) A 70-yr record of oxygen-18 variability in an ice core from the Tanggula 
Mountains, central Tibetan Plateau. Climate Past, 6(2), 219-227 (doi: 10.5194/cp-6-219-2010)

Jouzel J and Merlivat L (1984) Deuterium and oxygen-18 in precipitation: modeling of the isotopic effect during snow formation. J. Geophys. Res., 89(D7), 11749-11757 (doi: 10.1029/JD089iD07p11749)

Kalnay E and 21 others (1996) The NCEP/NCAR 40-year reanalysis project. Bull. Am. Meteorol. Soc., 77(3), 437-471 (doi: 10.1175/ 1520-0477(1996)077<0437:TNYRP >2.0.CO;2)

Kang S and 7 others (2002) Glaciochemical records from a Mt. Everest ice core: relationship to atmospheric circulation over Asia. Atmos. Environ., 36(21), 3351-3361

Kang S and 6 others (2007) Recent temperature increase recorded in an ice core in the source region of Yangtze River. Chinese Sci. Bull., 52(6), 825-831 (doi: 10.1007/s11434-007-0140-1)

Kreutz KJ, Wake CP, Aizen VB, Cecil LD and Synal H-A (2003) Seasonal deuterium excess in a Tien Shan ice core: influence of moisture transport and recycling in central Asia. Geophys. Res. Lett., 30(18), 1922 (doi: 10.1029/2003GL017896)

Kripalani RH and Kumar P (2004) Northeast monsoon rainfall variability over south peninsular India vis-à-vis the Indian Ocean dipole mode. Int. J. Climatol., 24(10), 1267-1282 (doi: 10.1002/ joc.1071)

Krishnamurthy V and Goswami BB (2000) Indian monsoon-ENSO relationship on interdecadal timescale. J. Climate, 13(3), 579-595 (doi: 10.1175/1520-0442(2000)013<0579:IMEROI> 2.0.CO;2)

Kurita $\mathrm{N}$ and Yamada $\mathrm{H}$ (2008) The role of local moisture recycling evaluated using stable isotope data from over the middle of the Tibetan Plateau during the monsoon season. J. Hydromet., 9(4), 760-775 (doi: 10.1175/2007JHM945.1)

Liu Y, Hou S, Wang Y and Song L (2009) Distribution of borehole temperature at four high-altitude alpine glaciers in central Asia. J. Mt Sci. [China], 6(3), 221-227 (doi: 10.1007/s11629-0090254-9)

Liu Z, Tian L, Yao T and Yu W (2008) Seasonal deuterium excess in Nagqu precipitation: influence of moisture transport and recycling in the middle of Tibetan Plateau. Environ. Geol., 55(7), 1501-1506 (doi: 10.1007/s00254-007-1100-4)

Meehl GA and Washington WM (1993) South Asian summer monsoon variability in a model with doubled atmospheric carbon dioxide concentration. Science, 260(5111), 1101-1104 (doi: 10.1126/science.260.5111.1101)

Merlivat L and Coantic M (1975) Study of mass transfer at the airwater interface by an isotopic method. J. Geophys. Res., 80(24), 3455-3464 (doi: 10.1029/JC080i024p03455)

Merlivat L and Jouzel J (1979) Global climatic interpretation of the deuterium-oxygen 18 relationship for precipitation. J. Geophys. Res., 84(C8), 5029-5033 (doi: 10.1029/JC084iC08p05029)

Naik SS, Thamban M, Rajakumar A, D'Souza W, Laluraj CM and Chaturvedi A (2010) Influence of climatic teleconnections on the temporal isotopic variability as recorded in a firn core from the coastal Dronning Maud Land, East Antarctica. J. Earth Syst. Sci., 119(1), 41-49 (doi: 10.1007/s12040-010-0006-9)

Nye JF (1963) Correction factor for accumulation measured by the thickness of the annual layers in an ice sheet. J. Glaciol., 4(36), 785-788

Ohata T and Ageta Y (1996) Data report of cryosphere research on Qingzang Plateau, 1991-1993 (Research Report) Institute for Hydrospheric-Atmospheric Sciences, Nagoya University, Nagoya [in Japanese]

Ohata T, Ueno K, Endoh N and Yinsheng Z (1994) Meteorological observations in the Tanggula Mountains, Qingzang (Tibet) Plateau from 1989 to 1993. Bull. Glacier Res., 12, 77-86

Pang Z and 6 others (2011) Processes affecting isotopes in precipitation of an arid region. Tellus $B, \mathbf{6 3}(3), 352-359$ (doi: 10.1111/j.1600-0889.2011.00532.x)

Paul D and Skrzypek G (2006) Flushing time and storage effects on the accuracy and precision of carbon and oxygen isotope ratios of sample using the Gasbench II technique. Rapid
Commun. Mass Spectrom., 20(13), 2033-2040 (doi: 10.1002/ rcm.2559)

Qin D and 9 others (2000) Evidence for recent climate change from ice cores in the central Himalaya. Ann. Glaciol., 31, 153-158 (doi: 10.3189/172756400781819789)

Rozanski K, Araguás-Araguás L and Gonfiantini R (1993) Isotopic patterns in modern global precipitation. In Swart PK, Lohmann KC, McKenzie JA and Savin S eds. Climate change in continental isotopic records (Geophysical Monograph 78) American Geophysical Union, Washington, DC, 1-36

Salati E, Dall'Olio A, Matsui E and Gat GR (1979) Recycling of water in the Amazon basin: an isotopic study. Water Resour. Res. 15(5), 1250-1258 (doi: 10.1029/WR015i005p01250)

Schwikowski M, Brütsch S, Palmer A, Jenk TM, Gäggeler HW and Leuenberger M (2005) Identification of precipitation source regions at Fiescherhorn Glacier using the deuterium excess. Laboratory of Radiochemistry and Environmental Chemistry, Paul Scherrer Institut, Villigen

Sengupta S and Sarkar A (2006) Stable isotope evidence of dual (Arabian Sea and Bay of Bengal) vapour sources in monsoonal precipitation over northern India. Earth Planet. Sci. Lett., 250(3-4), 511-521 (doi: 10.1016/j.epsl.2006.08.011)

Sontakke NA, Singh N and Singh HN (2008) Instrumental period rainfall series of the Indian region (AD 1813-2005): revised reconstruction, update and analysis. Holocene, 18(7), 1055-1066 (doi: 10.1177/0959683608095576)

Thompson LG, Yao T, Mosley-Thompson E, Davis ME, Henderson KA and Lin P (2000) A high-resolution millennial record of the south Asian monsoon from Himalayan ice cores. Science, 289(5486), 1916-1919 (doi: 10.1126/science.289.5486.1916)

Thompson LG and 7 others (2006) Holocene climate variability archived in the Purugangri ice cap on the central Tibetan Plateau. Ann. Glaciol., 43, 61-69 (doi: 10.3189/172756406781812357)

Tian L, Yao T, Sun W, Stievenard M and Jouzel J (2001a) Relationship between $\delta \mathrm{D}$ and $\delta^{18} \mathrm{O}$ in precipitation on north and south of the Tibetan Plateau and moisture recycling. Sci. China $D, 44(9), 789-796$

Tian LD, Yao TD, Numaguti A and Sun W (2001b) Stable isotope variations in monsoon precipitation on the Tibetan Plateau. J. Meteorol. Soc. Jpn, 79(5), 959-966

Tian L, Masson-Delmotte V, Stievenard M, Yao T and Jouzel J (2001c) Tibetan Plateau summer monsoon northward extent revealed by measurements of water stable isotopes. J. Geophys. Res., 106(D22), $28081-28088$

Tian L, Yao T, White JWC, Yu W and Wang N (2005) Westerly moisture transport to the middle of Himalayas revealed from the high deuterium excess. Chinese Sci. Bull., 50(10), 1026-1030 (doi: 10.1360/04wd0030)

Tian L and 7 others (2003) Oxygen-18 concentrations in recent precipitation and ice cores on the Tibetan Plateau. J. Geophys. Res., 108(D9), 4293 (doi: 10.1029/2002JD002173)

Trenberth KE and Stepaniak DP (2001) Indices of El Niño evolution. J. Climate, 14(8), 1697-1701 (doi: 10.1175/1520-0442(2001) 014<1697:LIOENO>2.0.CO;2)

Tsiouris S, Vincent CE, Davies TD and Brimblecombe P (1985) The elution of ions through field and laboratory snowpacks. Ann. Glaciol., 7, 196-201

Uchijima Z and Ohta S (1996) Climatic change scenarios for monsoon Asia based on $2 \times \mathrm{CO}_{2}-\mathrm{GCM}$ experiments. In Omasa $\mathrm{K}$, Kai K, Taoda H, Uchijima Z and Yoshino $\mathrm{M}$ eds. Climate change and plants in East Asia. Springer, Tokyo, 3-12

Uemura R, Matsui $\mathrm{Y}$, Yoshimura $\mathrm{K}$, Motoyama $\mathrm{H}$ and Yoshida $\mathrm{N}$ (2008) Evidence of deuterium excess in water vapor as an indicator of ocean surface conditions. J. Geophys. Res., 113(D19), D19114 (doi: 10.1029/2008JD010209)

Vuille M, Werner M, Bradley RS and Keimig F (2005) Stable isotopes in precipitation in the Asian monsoon region. J. Geophys. Res., 110(D23), D23108 (doi: 10.1029/2005JD006022)

Wang N, Yao T, Pu J, Zhang Y, Sun W and Wang Y (2003a) Variations in air temperature during the last 100 years revealed 
by $\delta^{18} \mathrm{O}$ in the Malan ice core from the Tibetan Plateau. Chinese Sci. Bull., 48(19), 2134-2138

Wang N, Thompson LG, Davis ME, Mosley-Thompson E, Yao T and $\mathrm{Pu} J$ (2003b) Influence of variations in NAO and SO on air temperature over the northern Tibetan Plateau as recorded by $\delta^{18} \mathrm{O}$ in the Malan ice core. Geophys. Res. Lett., 30(22), 5-12 (doi: 10.1029/2003GL018188)

Werner RA and Brand WA (2001) Referencing strategies and techniques in stable isotope ratio analysis. Rapid Commun. Mass Spectrom., 15(7), 501-519 (doi: 10.1002/rcm.258)

Yao T, Thompson LG, Mosley-Thompson E, Zhihong Y, Xingping Z and Lin PN (1996) Climatological significance of $\delta^{18} \mathrm{O}$ in north Tibetan ice cores. J. Geophys. Res., 101(D23), 29531-29537 (doi: 10.1029/96JD02683)

Yao $\mathrm{T}$ and 7 others $(2006) \delta^{18} \mathrm{O}$ records from Tibetan ice cores reveal differences in climatic changes. Ann. Glaciol., 43, 1-7

Yao T, Duan K, Xu B, Wang N, Guo X and Yang X (2008) Precipitation record since AD 1600 from ice cores on the central Tibetan Plateau. Climate Past, 4(3), 175-180 (doi: 10.5194/ cp-4-175-2008)

Yu W and 6 others (2008) Relationships between $\delta^{18} \mathrm{O}$ in precipitation and air temperature and moisture origin on a south-north transect of the Tibetan Plateau. Atmos. Res., 87(2), 158-169 (doi: 10.1016/j.atmosres.2007.08.004)

Zhang Y, Jianchen P and Ohate T (1994) The climatic feature at the Tanggula Mountain pass on the centre of Tibetan Plateau. J. Glaciol. Geocryol., 16(1), 41-48 [in Chinese with English summary]

Zhang Y and 6 others (2007) Seasonal air temperature variations retrieved from a Geladaindong ice core, Tibetan Plateau. J. Geogr. Sci., 17(4), 431-441 (doi: 10.1007/s11442-007-0431-0)

Zhang Y, Hou S, Liu Y and Pang H (2012) Preliminary study on the ENSO signal recorded by the $\delta^{18} \mathrm{O}$ series of ice core from Miaoergou flat-topped glacier, eastern Tienshan. Quat. Sci., 32(1), 59-66 (doi: 10.3969/j.issn.1001-7410.2012.01.07) [in Chinese with English summary]

Zhao H and 6 others (2012) Deuterium excess record in a southern Tibetan ice core and its potential climatic implications. Climate Dyn., 38(9-10), 1791-1803 (doi: 10.1007/s00382-0111161-7)

Zheng W, Yao T, Joswiak DR, Xu B, Wang N and Zhao H (2010) Major ions composition records from a shallow ice core on Mt. Tanggula in the central Qinghai-Tibetan Plateau. Atmos. Res., 97(1-2), 70-79 (doi: 10.1016/j.atmosres.2010.03.008)

MS received 23 February 2012 and accepted in revised form 4 October 2012 